\title{
Development of Learning Models for Functional Literacy Education Based on Folk Stories in PKBM Kota Padang
}

\author{
Irmawita $^{1, *}$ \\ ${ }^{I}$ Department of Non Formal Education, Faculty of Education, Universitas Negeri Padang, Padang, Indonesia \\ *Email: irmawita@fip.unp.ac.id
}

\begin{abstract}
Functional literacy education is one of non-formal education, which teaches citizens to learn literacy. The phenomenon that occurs is the low interest of learning citizens, and methods and learning strategies are still conventional. The approach and learning outcomes have not shown significant results as expected. Therefore it requires a new breakthrough in learning strategies. One of them is by introducing the organizers and tutors to make the learning atmosphere interesting and not boring. A community-oriented learning needs approach is needed, establishing cultural and local values that are close to their daily lives. The ideal of functional literacy programs is learning activities that give rise to interaction activities in an atmosphere of mutual learning between tutors and learning citizens in learning programs so that there are learning activities while working based on learning needs and functional skills. The purpose of development: (1) to find folklore based functional literacy education learning models. (2) analyzing and describing the practicality of folklore-based functional literacy education learning models based on community learning needs and productive skills. (3) analyzing and describing the effectiveness of functional literacy education learning models based on folklore in the Malin Kundang story script (4) analyzing and describing validity folklore-based functional literacy education learning models based on community learning needs and local skills. The development model through 4-D consists of the stages of defining, designing, developing, and distributing, then testing is limited. After that validation was carried out, analysis of the implementation of RPP in developing community-based learning was Malin Kundang's story. The results of the study obtained the story value based on folklore categorized as practical because the observation sheet 92.5 and the practical questionnaire averaged 93.3. Based on the conclusions, it can be revealed that the learning of functional literacy education based on folklore based on learning needs and local skills is a valid, practical and effective model to be applied Keywords: Learning Functional, Literacy Based on Folklore
\end{abstract}

\section{INTRODUCTION}

Education for all or EFA (Education for All), then this commitment was strengthened in Dakar in 2000 which became better known as the Dakar Declaration. The Dakar Declaration agreed to fight for 6 (six) Educational Action Frameworks for All (The Dakar Framework for Action Education for All ), namely: (1) expanding and improving the overall care and education of early childhood in a comprehensive manner, especially those that are very vulnerable and neglected; (2) gender equality in the education sector; (3) life skill programs for youth and adults; (4) eradicating illiteracy; (5) compulsory education in basic education; and (6) improving the quality of education. It is clear from the 6 (six) Dakar commitments that almost all of them are cultivated areas outside of school (non-formal education).

Functional literacy education is carried out annually by non-formal educational institutions such as the Community Learning Activity Center (PKBM) and
Community Social Institutions funded from the government budget. The implementation of this functional literacy education program is carried out by the implementer where the Tutor (educator) is the executor of learning. They collaborate in implementing functional literacy education programs in order to be free from illiteracy and improve the standard of living of underprivileged people, so program management should be based on community learning needs and utilization of local potential in the community where the learning program is implemented.

The importance of the role of functional literacy education in the community can be analyzed from various types of learning needs, according to Kusnadi[1], Functional literacy education includes (1) general or basic education, including literacy programs; (2) basic education on science and the environment; (3) productive skills education; and (4) education communicates using good and correct Indonesian.

The results of the author's preliminary study in March (2017) on institutions that organize programs in the city of Padang such as the Community Learning Activity Center 
(PKBM), conducted interviews with the PKBM chairman, and obtained information that those who had literacy were significant.

The focus of the problem of this research is "The compilation of models of functional literacy based learning activities based on folklore is taken from the story of Malin Kundang.

The purpose of this development research is to: a) find folklore-based functional literacy education learning models, 2) analyze and describe the practicalities of folklore-based functional literacy education learning models based on community learning needs and productive skills, 3) analyze and describe the effectiveness of educational learning models functional literacy based on folklore in the Malin Kundang story script, and d) Analyzing and describing the validity of folklore-based functional literacy education learning models based on community learning needs and local skills.

Reinforced by Kamil[2] "Programs developed in literacy education should be built on the basis of agreement and the needs of learning citizens". However, judging from the conditions of the target of literacy education, variations in the curriculum developed and the competencies determined must be understood by tutors, facilitators, and providers (education development). When literacy education programs are developed they understand what will be given and what must be (achieved) learning citizens. Therefore an understanding of the basic concepts of curriculum development must be flexible, understanding competence, and skills in how to explore and determine the needs of students' goals is a dominant factor that must be a reference.

Faisal[3] Folklore-based education is by designing the degree of community control over educational programs and the level of community control over education. Folklore-based education intended in this study is: community support in facilitating KF learning activities, involvement of community leaders and community education officers in motivating learning citizens, partnerships, from production institutions to cooperate in learning the skills of the KF program, the full ownership of Tutor in controlling all decisions about the program.

Morris[4] learning is a programmed and intentional effort to create conditions for learning activities to occur. This activity occurs educative interaction between learning people who conduct learning activities with learning resources that manage learning activities. Managing learning activities needs to be conditioned on aspects of planning, approaches, methods, materials, media and evaluation of learning.

Kusnadi[1] states "the target of functional literacy education is to serve citizens who are illiterate for the basic level, aged 15 to 60 years held for 6 months or minimum 36 meetings and taught in groups, where one study group consists of 10 people guided by one Tutor ".

The learning process needs to be developed in accordance with the chronological order as follows: (1) Hold group discussions about assignments in work; (2) Show tasks related to work assignments based on experience; (3) Identify principles and rules rationally and so on, combine them with work assignments; (4) Perform graphic symbolization of the above with pictures, numbers, arithmetic relationships, and appropriate words; (5) Summarize the results of the discussion and formulate written in short sentences; (6) Application of principles and rules according to the situation; (7) Ensure that work assignments should be viewed and selected as a study field to be observed in accordance with their interests in terms of time and money that will be considered systematically, accuracy or accuracy in order to encourage group members to achieve better standards in performance and productivity. Behavior of citizens learning during the learning process.

The development of learning models is carried out through identification of learning needs and local potential as resources that can be utilized to implement functional literacy education programs. The intended local potential is to utilize natural resources as the supporting capacity of the program and human resources as potential personnel who can drive the program. The implementation of the program can be realized through coordination and cooperation between organizers, tutors and learning citizens.

Based on the explanation above, the research roadmap scheme can be explained as shown in the picture below:

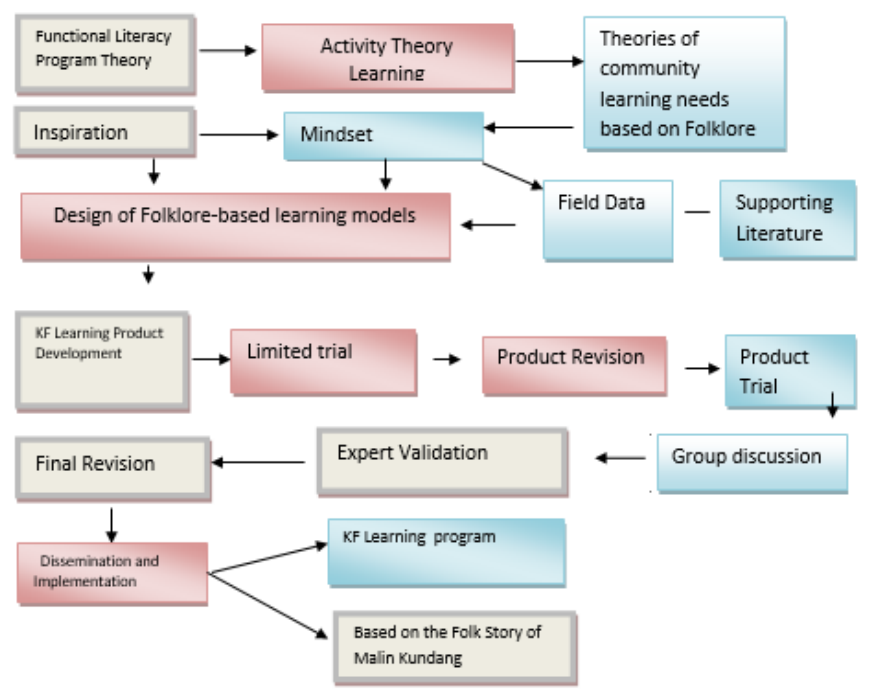

Picture 1 Procedure Flow Chart for the Development of the Malin Kundang Functional Literacy Program Based on Folk Stories 


\section{METHOD}

Research conducted is research and development ( R \& D). Research and Development (R \& D) according to Sugiyono[5] that Research and Development (R \& D) is a method used to produce certain products and test the effectiveness of these products. In line with this, Seels \& Ritchey[6] suggest that development research is a systematic study of planning, developing and evaluating teaching programs, processes and products that must meet the criteria for internal consistency and effectiveness. Furthermore, Sunarto[7] said that research and development is an effort to develop and produce a product in the form of media, learning materials and strategies used to overcome the problem of classroom learning / laboratory and to test the theory. In this case the research is to develop folklore-based learning models and based on the learning needs of the people analyzed based on learning planning, learning approaches, learning materials, learning methods and media and evaluation of learning outcomes in advanced level Literacy programs at Raso PKBM and Kurao PKBM Pagang Kuranji District, Padang City. Research and development is carried out on the adult education approach model by analyzing the folklore Malin Kundang, where while learning also learns various skills. The devices developed consist of syllabus, Learning Program Plan (RPP), learning media. It is hoped that the learning community will respond to learning activities which contain the principle of learning while telling stories, playing and working in various skills needed by the community.

The research development model is a $4-\mathrm{D}$ development model, which consists of four stages, namely: (1) define, (2) design, (3) develop, (4) disseminate.

At this stage begins by compiling learning tools for advanced level functional literacy education programs. Then compile the syllabus and lesson plan by analyzing the value in the story script on advanced level functional literacy education learning. The learning programs are various such as through storytelling, learning the required skills, such as craft skills, and experience in manners in a society known as Sumbang Dua Belas.

\section{RESEARCH RESULTS AND DISCUSSION}

Folklore-based learning that is analyzed in story texts on learning in functional literacy education learning groups is Malin Kundang's story which is a folk tale can be told as follows:

Once upon a time in Padang, West Sumatra, precisely by the Air Manis Beach, there was a mother named Mande Rubayah. He has a son Malin Kundang. Malin was very loved by his mother, because since childhood he had been killed by his father Malin Kundang.

Malin and his mother live in a fishing village. His mother is old, and she only works as a cake seller. One day Malin fell ill. His body suddenly became very hot. Mande
Rubayah is of course very confused. Never Malin fell sick like this. Mande Rubayah tried her best to treat Malin by bringing a physician.

Malin's almost floating life was finally saved thanks to his mother's hard work, and the blessing of Allah SWT. After recovering from his illness, he was increasingly loved. Thus Mande Rubayah, very fond of his child. Instead Malin is also very fond of his mother.

When he grew up, Malin said goodbye to his mother to go abroad. At that time there was indeed a large ship that docked at Air Manis Beach. "Mom, this is a good opportunity for me". Malin said. Not necessarily once a year, there are ships that dock at this beach. I will promise to change our destiny so that we will become rich."

Even though she was reluctant, finally Mande Rubayah allowe her son to leave. Malin is provided with seven packets of rice wrapped in banana leaves.

The days passed were slow for Mande Rubayah. Every morning and evening Mande Rubayah looked at the sea. She wondered, where is the child now? If there are big waves and storms, they hit the beach, their breasts pounding. She raised his hands up while praying to the Almighty God, so that her son survived the voyage. If there is a boat that comes close, she always asks about her son. But all crew members or captains never give satisfactory answers. Malin never left any items or messages to his mother. That's what Mande Rubayah does every day for years. Her body gets older with age. If she walks she has begun to bend over.

One day, Mande Rubayah got news from the captain who had brought Malin that Malin was now married to a beautiful girl, the daughter of a wealthy nobleman. She was glad to hear the news. She always prayed to God the Almighty so that her son survived and immediately returned to visit him.

"Mother is old Malin, when do you go home kid ......", moaned Mande Rubayah every night. But for months since she heard the news Malin had not yet come to see him. But she was sure that at some point Malin would definitely return.

Her wish came true. On a sunny day, from a distance a beautiful boat sailed, heading towards the beach. The ship was magnificent and multilevel. Kampong people think the ship belongs to a sultan or a prince. They welcomed him happily.

When the ship began to dock, it appeared that a pair of young people were standing on their feet. Their clothes sparkled thanks to the sun. Their faces brightly decorated with smiles. They looked happy because they were greeted with great fanfare. Mande Rubayah jostled, looked and approached the ship. Her heart was pounding hard, she was very sure that the young man was her beloved son Malin Kundang.

Not to mention the village elders had welcomed, Mother Malin first approached Malin. She immediately hugged Malin tightly. As if afraid of losing her child again. "My son Malin". She said holding back sobs because of happiness. "Why haven't you given the news for so long?" Malin was stunned because he was embraced by the old woman who was dressed in a tattered fray. He did not 
believe that the woman was his mother. As Malin recalled, his mother was a strong-bodied woman who held her tight, everywhere. Before he could think calmly, his beautiful wife spat while saying "Ohh! Is that bad woman your mother? Why are you lying to me" then she spat again, "Didn't you say your mother is a nobleman who is equal to us?"

Hearing his wife's words, Malin Kundang pushed the woman to the ground. Mande Rubayah hardly believes in the behavior of her child, she falls down while saying "Malin, my son Malin. I am your mother!"

Malin Kundang ignored his mother's words. His mind was confused because of his wife's words. If the woman is true to her mother, she will not admit it. He was ashamed of his wife. Seeing the woman inching to hug her leg, Malin looked at him while saying "Hey, old woman! My mother is not like you! Poor and filthy!"

The old woman lay in the sand. Many people were stunned and then returned to their homes. Unexpectedly, Malin who was loved, had the heart to do so. Mande Rubiyah fainted and lay alone. When she realized, Air Manis Beach was deserted. At sea she saw Malin's ship farther away. Her heart was jabbing like she was in a stick. Her hands were raised to the sky, she then exclaimed with a sad heart "O God Almighty, if he is not my son, I forgive his actions. But if it is true he is indeed my son, Malin Kundang, I beg for your justice, O God .......! "

Not long after the weather in the middle of the sea that had been bright, suddenly turned dark. The rain suddenly dropped with great depth. Somehow suddenly a big storm came. Hit the Malin Kundang's ship. Followed by a thunderous bolt of lightning. Instantly the ship was smashed to pieces, then the waves crashed to the beach. When the morning sun shines, the storm has subsided. At the foot of the hill there was a piece of ship that had become stone. That is the ship Malin Kundang. Not far from that place, a stone resembles a human body. That is said to be the body of Malin Kundang known as a rebellious child who was hit by the curse of his mother into stone. On the sidelines of the rock, swimming is anchovy, mullet and mackerel fish. It is said that the fish came from the fragments of his wife who kept looking for Malin Kundang.
Thus until now, if there were large waves hitting the stone that resembled ships and humans, there was a sound like the howls of human screams. How heartbreaking it sounds. Sometimes it sounds like a mourning person regrets himself "Forgive, Mom ...! Forgive ... Mom ...!" It is said that this is the voice of Malin Kundang.

A person who is disobedient to his parents, especially to his mother, that person will not be able to enter heaven unless he has received forgiveness from his mother.

This is the story of Malin Kundang, which is shared with expression, intonation and rhythm that are quite moved and impressive, in the atmosphere of learning activities. Besides learning activities in the learning community are not only learning activities but also taught various educational skills that are useful for their lives.

Residents studying Functional Literacy education consisted of two groups with 50 study residents, of which 30 people studied functional literacy education at PKBM Tenggang Raso, Sungai Sapih Village, Padang city and 20 people studied at PKBM Kurao Pagang, Kuranji District, Padang City as a group model trial.

Residents learn advanced level of literacy besides being taught to facilitate writing, reading and arithmetic and speak good and correct Indonesian, also facilitate ways of communicating and socializing with the community, are also taught skills in making mattress pads and bed covers, making tablecloths and making key toys bag of beads. For Functional Literacy in PKBM Kurao Pagang, making bag skills from knitting, making lantern lights, making flannel cloth that is beneficial for the learning community. The implementation of learning in PKBM Tenggang Raso, Sungai Sapih Village was held 3 times a week, namely Tuesday, Wednesday, and Sunday at $1.00 \mathrm{pm}$ until 6.00 $\mathrm{pm}$ at the PKBM location, guided by two KF program tutors namely Darima, SPd and Nani Winda Putri, SPd. Whereas in PKBM Kurao Pagang, Kuranji Subdistrict, Padang City, the learning period is three days, Tuesday, Thursday and Saturday starting from 2.00 p.m to 6.00 p.m with the Tutors being Avia Nola Putri Soliza and Dewi Yanti, SPd.

Social attitude assessments in functional literacy education programs are:

Table 1 Coverage of Social Attitude Assessment

\begin{tabular}{|l|l|}
\hline Social Attitude Assessment & $\begin{array}{l}\text { Respect and Live the Teachings of Religion That Are } \\
\text { Advised Social Attitude Assessment }\end{array}$ \\
\hline Social Attitude Assessment & $\begin{array}{l}\text { 1. } \\
\text { 2. }\end{array}$ \\
& 3. Donest \\
& 4. Responsibility \\
& 5. Tolerance \\
& 6. Be polite \\
& \\
& \\
\end{tabular}


Reference in assessment is an indicator, because indicators are a sign of achieving a competency. Indicators must be measurable. In the context of the attitude assessment in functional literacy education, indicators that appear that can be observed or observed from the Tutor as a representation of the attitude being assessed. The following are described several indicators of the attitudes of citizens learning in functional literacy education

Table 2 List Description of Indicators in Learning

\begin{tabular}{|c|c|}
\hline Attitude and Implementation & Indicator \\
\hline \multicolumn{2}{|l|}{ Spiritual attitude } \\
\hline $\begin{array}{l}\text { Respect and appreciate the } \\
\text { teachings of the religion adopted }\end{array}$ & $\begin{array}{l}\text { - } \text { Pray before and after doing something } \\
\text { - } \text { Carry out worship on time } \\
\text { - } \text { preetings at the beginning and end of the } \\
\text { - Give thanks and enjoy the gift of God Almighty } \\
\text { - Gratitude for human ability to control } \\
\text { themselves } \\
\text { - Say thanksgiving when successfully working on } \\
\text { - } \quad \text { Give up (tawakal) to God who has endeavored } \\
\text { - } \text { or made an effort } \\
\text { - } \text { Mamintain the environment around homes, } \\
\text { - Gaintaining good relations with God's creation } \\
\text { - } \text { bive thanks for the good relationships that have } \\
\text { Respect and respect others in worship }\end{array}$ \\
\hline \multicolumn{2}{|l|}{ Social attitude } \\
\hline $\begin{array}{l}\text { 1. Honest } \\
\text { Is behavior can be trusted in taking } \\
\text { joint decisions, actions and work }\end{array}$ & $\begin{array}{l}\text { - Confidence in your own abilities } \\
\text { - Express feelings as they are } \\
\text { - Submit to the authorized tools and materials } \\
\text { - } \text { found } \\
\text { - } \text { Mo the work as is } \\
\text { - Recognize errors or shortcomings }\end{array}$ \\
\hline $\begin{array}{l}\text { 2. Discipline } \\
\text { It is an action that shows an } \\
\text { orderly behavior and complies with } \\
\text { various provisions and regulations }\end{array}$ & $\begin{array}{l}\text { - Come on time } \\
\text { - Comply with common rules and regulations } \\
\text { - Work on and collect assignments according to } \\
\text { the time specified } \\
\text { - } \quad \text { Follow good and correct written language }\end{array}$ \\
\hline $\begin{array}{l}\text { 3. Responsibility } \\
\text { Is the attitude and behavior of } \\
\text { someone to carry out the duties and } \\
\text { obligations that he should do to } \\
\text { himself the community, environment } \\
\text { (nature, social and culture) of the State } \\
\text { and God Almighty. }\end{array}$ & 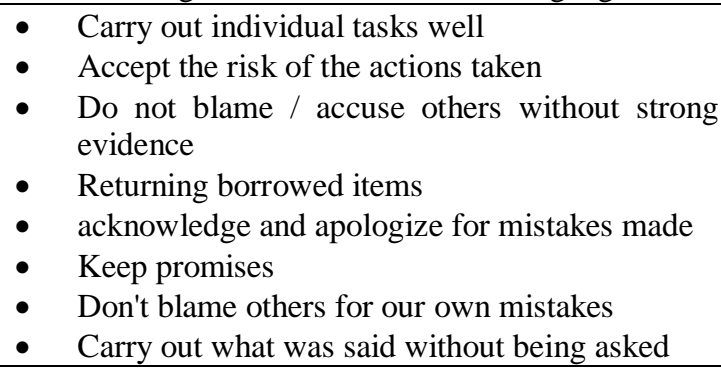 \\
\hline $\begin{array}{l}\text { 4. Tolerance } \\
\text { It is attitude and action that } \\
\text { respects, diversity of backgrounds, } \\
\text { views and beliefs }\end{array}$ & $\begin{array}{l}\text { - } \\
\text { - } \\
\text { Accept agreements even if they differ from their } \\
\text { - } \quad \text { Canions accept the shortcomings of others } \\
\text { - } \quad \text { Can forgive the mistakes of others } \\
\text { - } \text { diversity of background views and beliefs } \\
\text { - } \quad \text { Do not impose opinions or self-beliefs on others } \\
\end{array}$ \\
\hline
\end{tabular}


and ideas of others in order to understand others well

- Open to or willing to accept something new

5. Mutual cooperation
It is working together with others tasks and helping sincerely.
- Actively involved and devoted to work together

- Willingness to do assignments as agreed

- Willing to help others without expecting reward

- Active in group work

- Focus on group goals

- Do not prioritize personal interests

- Look for ways to overcome differences of opinion / thoughts between yourself and others

- Encourage others to work together to achieve common goals.

\begin{tabular}{ll|ll} 
6. Be polite or polite & - Respect for older people
\end{tabular}

It is a good attitude in association both in language and behavior. Normality of politeness is relative, meaning that what is considered good / polite at a certain place and time can be different in other places and times

- Do not say dirty, rough and obscene words

- Not easily offended by other people's words

- Do not denounce the conversation at the wrong time

- $\quad$ Say thank you after receiving help from others

- $\quad$ Being 3S (greeting, smiling, greeting)

- Request permission when entering another person's room or using someone else's item

- Treating other people as yourself is treated

7. Confidence $\quad \bullet \quad$ Argue or take action without hesitation

Is a mental or psychological - Able to make decisions quickly condition of a person who gives strong confidence to act and act
In the context of assessing attitudes and responsibilities for learning citizens in advanced level functional literacy education, the signs raised by learning, learning interactions between tutors and learning citizens can be
- Not easily discouraged

- Not awkward in acting

- Dare to present in front of the learning community

- Dare to argue, ask questions, or answer questions

\section{LEARNING IMPLEMENTATION PLAN (RPP)}

Education Unit: Functional Literacy Education

Semister: Advanced KF

Subjects: Folklore Education

Typic / Theme: Malin Kundang Anak Durhaka

Meeting to: III

Time allocation: $3 \times 45$

\section{A. CORE COMPETENCIES}

Respect, obey and interpret honest behavior, discipline, responsibility, tolerance, mutual cooperation, courtesy and courtesy and mutual respect in communicating and interacting effectively with the surrounding social and natural environment within the scope of their association and civilization.

\section{B. BASIC COMPETENCY}

Understand and interpret the values of civilization from being honest and polite and respecting the views of the nation and state. 


\section{COMPETENCE ACHIEVEMENT INDICATORS}

1. Identify honesty and courtesy as one of the values contained in the philosophy of the nation and a devout nation that believes in Allah the Almighty.

2. Explain the importance of honesty, courtesy, mutual respect and responsibility, as one of the values contained in the meaning of life and the meaning of association in social life.

3. Apply the meaning of honesty, courtesy, respect, respect and responsibility and work together as a philosophy of life for citizens, society and family.

\section{TEACHING OBJECTIVES}

1. Identifying the forms of Malin Kundang folklore as national history and culture that are quite well-known and become family life which are presented in the form of folklore, Malin Kundang anak durhaka.

2. Grouping the forms of positive attitudes and negative attitudes which are cultural values of politeness, honesty, responsibility, mutual respect, cooperation, tolerance, selfconfidence, mutual cooperation and so on, which is a courtesy that must be possessed, especially for women.

3. Analyzing the value of honesty and respecting it as a positive attitude as a religious community, having national citizenship, living in a community and having a family in the surrounding environment in the text of the story communicated.

4. Through discussion, the learning community can conclude the meaning of a positive attitude of honesty, tolerance and responsibility, which is contained in life as a religious, national and state people in their family and surrounding communities.

5. Through a reflection of some learning citizens, they can recount the story of Malin Kundang and interpret attitudes, actions and behaviors of various positive and negative attitudes in various lives between family, neighbors, and community.

\section{E. LEARNING MATERIALS}

Developing an honest, tolerant, responsible attitude and living together with mutual respect and respect from Malin Kundang's child who is a lawless child.

1. A rural child in West Sumatra lives his mother Mande Rubayah and her son Malin Kundang, while her father has long since died. From childhood they were raised with love and sincerity of heart. They live on the coast not far from the beach of Air Manis, the city of Padang.

2. When they grow up their children say goodbye to going abroad, riding a big ship. He experienced many obstacles in his life on the ship for years, so at certain times he became the captain of the ship. Then he married his wife who was a former child of the captain of the ship.

3. At certain times, he sailed to his place of origin, where he had been waiting for his mother and the community, he was considered forgetting that the old man was his child and did not consider it his child. Even Malin cursed and insulted the old parent as well as his wife.

4. The old woman is sad, with a sad heart, asking the Almighty for justice and your guidance.

5. Not long after the weather darkened, the rain fell very heavy, a big storm, hit the big ship, the ship was destroyed, so the waves crashed to the beach.

6. When in the morning, it was seen that the ship's pieces had become stone, it was considered fragile that the ship Malin Kundang and his family and relatives had become stone. Malin Kundang became a rebellious child because of his mother's curse. There 
appears a stone that resembles a human body. Nowadays, it is famous for Air Manis Beach as a tourist spot for the community.

\section{F. LEARNING METHODS}

1. Approach : Scientific

2. Methods : Lecture, ask questions, discussion, tell stories, simulate, and communicate interactively

\begin{tabular}{|c|c|c|c|}
\hline Phase & $\begin{array}{l}\text { Expected activities from tutors and } \\
\text { speakers }\end{array}$ & $\begin{array}{l}\text { Activities expected from the } \\
\text { learning community }\end{array}$ & time \\
\hline preliminary & $\begin{array}{l}\text { 1. Say hello and communicate } \\
\text { 2. preparing learning tools and } \\
\text { materials } \\
\text { 3. Instruct the learning community } \\
\text { to prepare the learning conditions }\end{array}$ & $\begin{array}{l}\text { 1. Answering greetings, } \\
\text { communicating } \\
\text { 2. focus attention and help } \\
\text { prepare learning tools and } \\
\text { materials }\end{array}$ & 30 minutes \\
\hline Core activities & $\begin{array}{l}\text { 1. Tells people to learn about Malin } \\
\text { Kundang's script } \\
\text { 2. Instruct the learning community to } \\
\text { analyze honesty, courtesy, and help } \\
\text { each other through story texts }\end{array}$ & $\begin{array}{l}\text { 1. Residents learn to listen } \\
\text { and live the stories that are } \\
\text { read } \\
\text { 2. Citizens learn to analyze } \\
\text { honesty, courtesy and help } \\
\text { each other }\end{array}$ & 120 minutes \\
\hline Closing & $\begin{array}{l}\text { 1. Invite the learning community to } \\
\text { conclude the learning outcomes } \\
\text { 2. Instruct to make an assessment of } \\
\text { self instruments }\end{array}$ & $\begin{array}{l}\text { 1. Actively participate in } \\
\text { drawing conclusions on } \\
\text { learning outcomes } \\
\text { 2. Making reflexes through } \\
\text { the instruments shared by } \\
\text { tutors } \\
\text { 3. Make a self-assessment } \\
\text { instrument in writing }\end{array}$ & 30 minutes \\
\hline
\end{tabular}

\section{G. LEARNING DEVICES}

1. Handbook on Tutors

2. Learning community guide book

3. Books of relevant sources

\section{H. VALUE}

1. Assessment is carried out in two forms, namely:

a. Assessment of processes carried out during the learning process takes place

b. Assessment of results, obtained through analysis of story script and filling in questionnaires

2. The instrument:

a. Observation sheet (attached)

Conducting observations of the learning community during learning takes place mainly related to honesty, tolerance, cooperation and confidence.

b. Question sheet (attached)

In the form of items that must be answered by the learning community. 


\section{CONCLUSIONS AND SUGGESTIONS}

After all stages of research are carried out, the researcher can finally conclude the results of research on the development of folklore-based functional literacy education learning based on learning needs and local skills, by analyzing Malin Kundang's story, namely:

- In order for the process of developing honesty and positive behavior in the development of Malin Kundang folklore-based functional literacy education, 4 D development stages can be carried out, namely; define, design, development and dissemeate.

- Functional literacy education learning model based on folklore based on community learning needs and local skills, can be categorized as practical, because the observation and interview sheets, obtained an average score of 92.5 and in the practicality questionnaire the score obtained 93.3 so that this model is practical to apply .

- The learning model by analyzing the value of the story script in developing a positive attitude and behavior with productive skills, can be categorized as valid, because based on the results of data processing, it is found that no one gets a value below 0.36 . This shows that this model is very valid to be applied in learning.

- Folklore-based learning models based on learning needs and local skills are categorized as effective, because the percentage increase in mastery of learning citizens towards positive attitudes in the category is very good. Questionnaire assessment has increased by $24.66 \%$ on the level of knowledge (cognitive), 22.22\% in the psychomotor domain (skills) and a significant increase in the affective domain which is $43.33 \%$, so this model is very effective to apply.

\section{REFERENCES}

[1] Kusnadi, Program Keaksaraan Fungsional di Indonesia. Jakarta: Mustika Aksara, 2004.

[2] Irmawita Irmawita, "Deskripsi Kepemimpinan Ketua Lembaga Sosial Kemasyarakatan (LSM) dalam Melaksanakan Program Pendidikan Nonformal," Pedagog. - J. Ilm. Ilmu Pendidik., vol. XIII, no. 1, pp. 66-75, 2012.

[3] E. Suryanto, "Model Pendidikan Karakter Berbasis Pembelajaran Apresiasi Cerita Rakyat dengan Menggunakan Media Wayang Kancil," J. Pendidik. Bhs. dan Sastra, vol. 17, no. 2, pp. 253-265, 2017.

[4] R. A. Putra, M. Kamil, and J. R. Pramudia, "Penerapan Metode Pembelajaran Mandiri dalam Meningkatkan Hasil Belajar Peserta Didik (Studi pada Program Pendidikan Kesetaran Paket C di PKBM Bina Mandiri Cipageran)," J. Pendidik. Luar Sekol., vol. 1, no. 1, pp. 23-36, 2017.
[5] M. D. V. Banggur, R. Situmorang, and Rusmono, "Pengembangan Pembelajaran Berbasis Blended Learning pada Mata Pelajaran Etimologi Multimedia," JTP - J.

Teknol. Pendidik., vol. 20, no. 2, pp. 152-165, 2018.

[6] R. Richey and Nelson, Developmental Research. New York: McMillan Publishing Company, 1996.

[7] Sunarto, Manajemen Sumber Daya Manusia Strategik. Yogyakarta: Amus, 2005. 